\title{
Sickle cell disease: Classification of clinical complications and approaches to preventive and therapeutic management.
}

Samir K. Ballas

Thomas Jefferson University

Follow this and additional works at: https://jdc.jefferson.edu/medfp

Part of the Hematology Commons

Let us know how access to this document benefits you

\section{Recommended Citation}

Ballas, Samir K., "Sickle cell disease: Classification of clinical complications and approaches to preventive and therapeutic management." (2018). Department of Medicine Faculty Papers.

Paper 239.

https://jdc.jefferson.edu/medfp/239

This Article is brought to you for free and open access by the Jefferson Digital Commons. The Jefferson Digital Commons is a service of Thomas Jefferson University's Center for Teaching and Learning (CTL). The Commons is a showcase for Jefferson books and journals, peer-reviewed scholarly publications, unique historical collections from the University archives, and teaching tools. The Jefferson Digital Commons allows researchers and interested readers anywhere in the world to learn about and keep up to date with Jefferson scholarship. This article has been accepted for inclusion in Department of Medicine Faculty Papers by an authorized administrator of the Jefferson Digital Commons. For more information, please contact: JeffersonDigitalCommons@jefferson.edu. 


\title{
Sickle Cell Disease: Classification of Clinical Complications and Approaches to Preventive and Therapeutic Management
}

\author{
Samir K. Ballas MD \\ Cardeza Foundation for Hematologic Research, Department of Medicine, Sidney Kimmel
} Medical College, Thomas Jefferson University, Philadelphia PA USA

Corresponding Author:

Samir K. Ballas MD FACP

Cardeza Foundation for Hematologic Research

1020 Locust Street

Philadelphia, PA 19107

E-mail: samir.ballas@jefferson.edu

Phone: 856-745-6380

Fax: 856-795-0809

\begin{abstract}
Word Count: 165
Text Word Count: 8634w

Number of Figures: 1

Number of Tables: 3

Number of References: 176
\end{abstract}

Running Head: Complications and treatment of SCD

Key Words: Sickle cell disease, sickle cell anemia, complications, management

Financial Disclosure: The author claims no potential conflicts of interest. 


\begin{abstract}
Sickle cell disease (SCD) is an inherited disorder of hemoglobin structure that has no established cure in adult patients. Cure has been achieved in selected children with sickle cell anemia (SCA) using allogeneic bone marrow transplantation or cord blood transplantation. SCD is essentially a triumvirate of (1) pain syndromes, (2) anemia and its sequelae and (3) organ failure, including infection. Pain, however, is the hallmark of SCD and dominates its clinical picture throughout the life of the patients. The prevalence of these complications varies with age from infancy through adult life. However, pain, infections and anemia requiring blood transfusion occur throughout the life span of affected patients. The overall medical care of patients with SCD in developed countries has improved such that their life expectancy has almost doubled since 1951. Currently, there are at least five major approaches for the general management of SCD and its complications. These include (i) symptomatic management, (ii) supportive management, (iii) preventive management, (iv) abortive management, and (v) curative therapy.
\end{abstract}




\section{Introduction}

Hemoglobinopathies are inherited disorders of the structure and/or function of hemoglobin $(\mathrm{Hb})$. They are broadly divided into two major groups: structural variants and thalassemias. Structural variants are, most commonly, the result of single base mutations in the globin genes. Thalassemias are characterized by decreased synthesis of any one or more of the globin chains.

The sickle mutation is the result of a single base change (GAG $\rightarrow$ GTG) in the sixth codon of exon 1 of the $\beta$-globin gene responsible for the synthesis of the $\beta$-globin polypeptide of the $\mathrm{Hb}$ molecule ( $\alpha 2 \beta 2)$. This change, in turn, results in replacement of the normal glutamic acid (E/Glu) with valine (V/Val) at position 6 of the $\beta$-globin chain and the formation of sickle $\mathrm{Hb}[1-3]$.

Over two million U.S. residents are estimated to be either heterozygous or homozygous for the genetic substitution. Most of those affected are of African ancestry or self-identify as Black; a minority are of Hispanic or southern European, Middle Eastern, or Asian Indian descent [4]. It is estimated that between 70,000 and 100,000 African Americans have SCD. Although SCD is associated with major morbidity, currently more than 90 percent of children with SCD in the United States and the United Kingdom survive into adulthood [5-7]. However, their lifespan remains shortened by two or three decades compared to the general population $[8,9]$.

\section{Classification of Sickle Cell Disorders}


Sickle cell disease comprises a group of clinically significant hemoglobinopathies in which the sickle gene is inherited from at least one parent. Sickle cell anemia (SCA) is the homozygous state where the sickle gene is inherited from both parents. Sickle cell syndromes also result from the co-inheritance of the sickle gene with $\mathrm{Hb} \mathrm{C}$ gene giving rise to $\mathrm{Hb} \mathrm{SC}$ diseases, with $\beta$-thalassemia genes $\left(\beta^{0}\right.$ or $\beta^{+}$) giving rise to sickle $-\beta^{0}$-thalassaemia or sickle $-\beta^{+}$thalassemia respectively or with other $\beta$-globin structural variants giving rise to other combinations such as HbSO Arab, HbSD disease, and so. The most prevalent SCD types include homozygous $\mathrm{Hb} \mathrm{SS}$ and the compound heterozygous conditions $\mathrm{HbS} \beta^{0}$-thalassemia, $\mathrm{HbS} \beta^{+}$thalassemia, and $\mathrm{Hb} \mathrm{SC}$ disease. $\mathrm{Hb} \mathrm{SS}$ and $\mathrm{HbS} \beta^{0}$-thalassemia are clinically very similar and therefore are commonly referred to as SS or SCA; these genotypes are associated with the most severe clinical manifestations. Certain complications of SCD may be more common in one category than another. Thus, frequent painful crises, severe anemia that requires blood transfusion and acute chest syndrome (ACS) are more common in SCA than other types of SCD. Sickle retinopathy and otologic disorders, on the other hand, are more common in $\mathrm{Hb} \mathrm{SC}$ disease than in SCA. It must be emphasized that the order of severity in SCD is based on population statistics. Thus, if one compares the overall clinical picture of 100 patients with SCA, for example, with that of 100 patients with $\mathrm{Hb}$ SC disease then the latter will be milder as far as frequency of painful episodes, morbidity and mortality are concerned. On the individual basis, however, there are exceptions. Thus, an individual patient with SCA may have a mild disease whereas an occasional patient with S- $\beta^{+}$-thalassemia may have a severe disease.

\section{Genetics and Epigenetics}

Sickle cell syndromes can also be divided into subcategories depending on the $\alpha$ genotypes and $\beta$ haplotypes [10-12]. About $65 \%$ of patients with SCA have normal $\alpha$ genotypes 
$\left(\beta^{\mathrm{S}} \beta^{\mathrm{S} ;} \alpha \alpha / \alpha \alpha\right)$, 30\% have one $\alpha$ gene deleted $\left(\beta^{\mathrm{S}} \beta^{\mathrm{S}} ;-\alpha / \alpha \alpha\right)$, and the remaining $5 \%$ have two $\alpha$ genes deleted $\left(\beta^{\mathrm{S}} \beta^{\mathrm{S}} ;-\alpha /-\alpha\right)$. The effect of $\alpha$ gene deletion on the clinical picture of sickle cell syndromes is controversial. Generally speaking, $\alpha$ gene deletion is associated with milder anemia [13] and less blood transfusion. The increased $\mathrm{Hb}$ level associated with $\alpha$ gene deletion, however, presumably increases the blood viscosity, which is often accompanied by increased frequency of painful crises $[14,15]$ and vaso-occlusive episodes such as avascular necrosis (AVN) [16, 17]. Recently, Renoux et al [18] observed increased frequency of crises in children with alpha-thalassemia but it was not explained by increased blood viscosity. Instead, children with alpha-thalassemia had greater RBC deformability and RBC aggregation. The number of patients studied, however, was relatively small and the diagnosis of avascular necrosis was not ruled out [18]. The effect of $\alpha$ gene deletion on the clinical picture is best illustrated in SCA with two $\alpha$ gene deletions. Table 1 lists the unique features of this type of SCD $[19,20]$. Noteworthy is that HbA2 is elevated in SCA with two $\alpha$ gene deletions, a finding that confuses this diagnosis with $S \beta^{0}$ thalassemia that is, typically, also associated with elevated $\mathrm{HbA} 2$ levels. The clinical picture, family history, hematological data and molecular diagnostics can differentiate the two diagnoses [20].

$\beta$-Haplotypes refer to the nucleotide sequence 5' and 3' to the sickle gene. Three major types have been described in Africans and African Americans [11]. These are the Senegalese (Sen), Benin (Ben) and Central African Republic (CAR) haplotypes. The significance of these haplotypes pertains to their effect on $\mathrm{Hb} \mathrm{F}$ production. It has been established that the higher the $\mathrm{Hb} \mathrm{F}$ level, the milder is the SCA [15, 21]. Again, these conclusions are based on population data and may not apply to an individual patient. 
Epigenetic factors that could affect phenotypic expression include the environment, aging, drugs/pharmaceuticals and diet. The exact mechanism of action of epigenetic factors at the molecular level is not well known. It seems that some drugs may cause methylation or demethylation of DNA or modification of histones resulting in activation or deactivation of certain genes that could affect the phenotypic expression of the gene in question [22].

\section{Genetic Markers}

Sickle cell disease is a complex genetic disorder characterized by intricate genotypic/phenotypic interactions that include correlations among multiple genetic and environmental markers and modifiers. Genetic markers may predict the severity of the disease and the possible or probable incidence of certain complications. This, in turn, allows for the implementation of certain therapeutic measures that may prevent or ameliorate the severity of some of these complications. Traditional approaches to identify genetic markers have included studies of the transgenic sickle cell mouse and natural history studies and family pedigrees [23, 24]. With the advent of the Human Genome Project, novel genetic polymorphisms associated with disease have been identified, thus allowing for the performance of genetic association studies [24-31].

Although these findings are novel and interesting, their validity and utility in predicting and treating the clinical complications of SCD should be confirmed by large controlled multiinstitution studies. The studies performed to date are too small to make definite conclusions. 


\section{Other Factors}

In addition to the factors mentioned above, there is growing evidence that psychosocial and environmental factors precipitate vaso-occlusion and affect the frequency and severity of painful episodes. Physical stress, trauma, dehydration and infections are such known factors.

\section{Clinical Complications of Sickle Cell Disease}

Major complications of SCD include three sets of clinical adverse effects: (1) pain syndromes, (2) hemolytic anemia and its sequelae and (3) organ damage/failure. The prevalence of these complications varies with age from infancy through adult life as shown in Figure 1. However, pain, infections and anemia requiring blood transfusion occur throughout the life span of affected patients.

\section{Pain Syndromes}

\section{The Acute Painful Vaso-occlusive Crisis (VOC)}

Sickle cell pain has unique features. Pathophysiologically, it is nociceptive (ie, secondary to tissue damage). It may be acute or chronic, somatic or visceral, unilateral or bilateral, localized or diffuse and mild, moderate or severe [32]. Typically, VOCs affect long bones and joints, with the low back frequently reported site of pain [33]. Other regions of the body, including the scalp, face, jaw, abdomen, and pelvis, may be involved. A severe acute sickle cell painful episode has been defined as one that requires treatment in a medical facility with parenteral opioids for 4 or more hours $[34,35]$. The occurrence of three or more such crises indicates that the affected patient has severe SCD. The words most often used to describe sickle 
pain include "throbbing," "sharp," "dull," "stabbing," and "shooting," in decreasing order of frequency [33].

Objective signs of a VOC, such as fever, leukocytosis, joint effusions, and tenderness, occur in about $50 \%$ of patients at initial presentation [13]. During the evolution of the VOC, however, objective laboratory signs become evident in most patients, provided that these parameters are determined serially [36]. The VOC that requires hospitalization appears to evolve along four distinct phases: prodromal, initial, established, and resolving [37]. Each phase may be associated with certain clinical and laboratory findings. As the pain of a VOC intensifies, the percentage of dense RBC increases with a concomitant decease in RBC deformability. Some patients develop hyperhemolysis during the evolution of the VOC, with decrease in $\mathrm{Hb}$ level and increase in the reticulocyte count [37]. As pain resolves, the pattern is reversed, with a decrease in the number of dense red cells and an increase in RBC deformability [36].

\section{Chronic sickle cell pain}

\section{Avascular Necrosis}

Avascular necrosis (also called ischemic necrosis or osteonecrosis) is the most commonly observed complication of SCD after the number of VOCs in adults. Although it tends to be most severe and disabling in the hip area, it is a generalized bone disorder in that the femoral and humeral heads as well as the vertebral bodies may be equally affected. The limited terminal arterial blood supply and the paucity of collateral circulation make these three areas especially vulnerable to sickling and subsequent bone damage. In the Cooperative Study of Sickle Cell Disease (17) that included 2804 patients, with SCA and $\alpha$-gene deletion had a higher incidence of AVN because the relatively high hematocrit increases blood viscosity and thus, enhances 
microvasculopathy in the aforementioned anatomic sites $[16,17]$. The mean corpuscular volume (MCV) and AST levels were reported to be negatively correlated with avascular necrosis especially in patients with homozygous alpha gene deletion [17]. In a study involving about 100 patients with SCA, Lemonne et al. [38] found no difference in blood viscosity between patients with and those without osteonecrosis, despite difference in hematocrit/Hb. Together, all these findings suggest that $\mathrm{Hb}$ seems to have a negative effect on the frequency of AVN irrespective of its effect on viscosity. The roles of $\mathrm{Hb} / \mathrm{Hct}$, viscosity, deformability and aggregation in the pathophysiology of certain complications of SCD need further studies.

Medical treatment of AVN is symptomatic and includes providing non-opioid and/or opioid analgesics for pain relief as well as physical therapy. Advanced forms of the disease require total bone replacement. Core decompression in the management of AVN appears to be effective if done in the early stages of AVN [39]. This, however, was not supported by a prospective randomized multi-center comparing physical therapy alone with core decompression and physical therapy for femoral head AVN in 46 patients with SCD [40]. Physical therapy alone appeared to be as effective as hip core decompression followed by physical therapy in improving hip function and postponing the need for additional surgical intervention at a mean of three years treatment. Results of hip arthroplasty in patients with SCA are not as encouraging as results of arthroplasty performed for arthritic hip [41]. Placement of an internal prosthesis may be difficult owing to the presence of hard sclerotic bone in patients with SCD. Other problems associated with hip arthroplasty in these patients include an increased incidence of infection [42, 43], a failure rate of about $50 \%$ and a high morbidity due to loosening of both cemented and 
uncemented prosthesis. Recent techniques of arthroplasty may improve the life expectancy of hip prostheses [44].

\section{Leg ulcers}

Leg ulceration is a painful and sometimes disabling complication of SCA that occurs in 5 to $10 \%$ of adult patients. The most common site for the appearance of leg ulcers is the distal third of the leg, especially on the inner area, just above the ankle and over the medial melleoli. Ulceration involves the skin and underlying tissues of the involved areas. The deeper the ulcer the more severe. Leg ulcers are classified into stages depending on their depth and not surface area. Severe pain may necessitate the use of opioid analgesics. The use of topical analgesics seems to be effective in relieving pain and decreasing the use of oral analgesics, especially opioids [45].

Leg ulcers are more common in males and older patients, and less common in patients with $\alpha$-gene deletion, high total $\mathrm{Hb}$ level or high levels of $\mathrm{Hb} \mathrm{F}$ [19]. Leg ulcers seem to be more common in patients who are also carriers of the CAR $\beta$-gene cluster haplotype [46]. As was mentioned above leg ulceration seems to be associated with priapism, pulmonary hypertension and death in a subtype of SCD characterized by high levels of lactate dehydrogenase (LDH) as a marker of hyperhemolysis.

Treatment of leg ulcers includes wound care using wet to dry dressings soaked in saline or Burrow's solution. With good localized treatment, many ulcers heal within a few months. Oral zinc sulfate therapy (660 mg per day) may be beneficial for some patients [47]. However, a Cochrane review [48], showed that oral zinc for arterial or venous leg ulcers due to causes other than SCD had no significant difference compared to placebo. Leg ulcers that persist more than 6 
months present a challenge to the treating physician and the patient. In addition, survival of patients with chronic leg ulcers seems to be decreased compared to patients without leg ulcers [49].

Certain modalities for the management of leg ulcers that are not commonly used in SCD include topical application of platelet-derived growth factor prepared either autologously (Procuren) [50] or by recombinant technology (Regranex) [51], topical sodium nitrite for chronic leg ulcers [52], and the use of cultured skin grafts [53]. In addition, mānuka honey from New Zealand has been reported to heal diabetic foot ulcers [54, 55]. Amputation, a last resort for recalcitrant and severely painful ulcers, is rarely used [56, 57].

The induction of $\mathrm{Hb}$ F production by hydroxyurea (HU) [34] would imply that it may prevent or heal leg ulcers in patients with SCD. However, HU has been reported to be associated with leg ulcers in patients with myeloproliferative disorders $[58,59]$. Whether the same association exists in patients with SCD is controversial. Leg ulcers were a common complication among 123 adult patients treated with HU in a retrospective French study [60]. Although controlled studies have not been reported to support the role of $\mathrm{Hb} \mathrm{F}$ induction in the management of leg ulcers, future randomized, multicenter trials of HU may provide further information on this subject.

\section{Pain between Crises}

Some patients with SCD complain of pain between VOCs and take opioids with or without nonopioid analgesics on a chronic basis. They have no evidence of precipitating cause such as infection, dehydration, or ischemia. Many of these patients are often referred to as having 
chronic pain despite the fact their pain is not similar to other chronic pain syndromes such as low back pain in the general population, fibromyalgia, osteoarthritis, migraine, etc.

\section{Neuropathy and neuropathic pain}

Neuropathy and neuropathic pain are not the same and not all patients with neuropathy have pain. Neuropathic pain is not well documented as a complication of SCD. The scales to assess neuropathic pain are different than those used in assessing sickle cell pain and their use has not been validated in SCD. Neuropathy, especially peripheral neuropathy, has been reported in patients with SCD, albeit uncommonly. Mental nerve neuropathy (AKA numb chin syndrome) is the most commonly reported neuropathy in SCD usually associated with VOC. More studies are needed to determine the prevalence of neuropathy and neuropathic pain in patients with SCD and to find whether these are complications of the disease itself or due to co-morbidities [61].

\section{Hematological Manifestations}

\section{Hemolytic anemia and its sequelae}

Sickle cell anemia is characterized by normochromic, normocytic anemia with a mean $\mathrm{Hb}$ of $7.8 \pm 1.13$ and a mean corpuscular volume (MCV) of $90 \mathrm{fl}$. The presence or absence of $\alpha-$ gene deletion has an effect on the anemia, the indices and the hemoglobin electrophoresis

pattern. Thus, patients with SCA and homozygous $\alpha$-thal $2\left(\beta^{\mathrm{S}} \beta^{\mathrm{S}} ;-\alpha /-\alpha\right)$ have milder anemia, a lower reticulocyte count, a low MCV and a high $\mathrm{Hb}$ A2 level. Both the white blood cell and platelet counts are increased in SCA due to increased marrow activity secondary to chronic hemolysis and, in the case of SCA, to "autosplenectomy", where platelets are not stored in the spleen. Normally, about one-third of circulating platelets are stored in the spleen and patients with splenectomy typically have high platelet counts. Patients with splenomegaly (S- $\beta$ - 
thalassemia, Hb SC disease and SCA with $\alpha$-thalassemia) typically have low or low-normal platelet counts, depending on the degree of splenomegaly.

Patients with $S-\beta^{0}$-thalassemia have a hematological picture that is characterized by microcytosis, hypochromia, high $\mathrm{Hb}$ A2 levels and variable $\mathrm{Hb}$ F values. The anemia in $\mathrm{Hb}$ S- $\beta^{+}-$ thalassemia is mild and usually with $\mathrm{Hb}$ level greater than $10 \mathrm{~g} / \mathrm{dL}$. Hb SC disease is typically characterized by microcytic and hyperchromic RBC indices.

In addition to the chronic hemolytic anemia typical of SCD, patients with SCA may develop other types of anemia. Hyperhemolysis (or hyperhemolytic crisis) is characterized by a marked drop in $\mathrm{Hb}$ with evidence of increased red blood cell destruction in the absence of other identifiable causes such as splenic or hepatic sequestration. The decrease in $\mathrm{Hb}$ should be $\geq 20 \%$ from baseline and the increase in reticulocyte by $25 \%$ or presence of nucleated $\mathrm{RBC}$ in the peripheral smear. Moreover, there should be evidence of hemolysis [increased LDH, unconjugated bilirubin, or aspartate aminotransferase (AST)], compared with baseline without recovery from bone marrow suppression [62]. Hyperhemolysis may be caused by infection (example, mycoplasma pneumonia), a co-existent G6PD deficiency with exposure to oxidant stress or by a delayed hemolytic transfusion reaction. Aplastic crisis characterized by a decrease both in $\mathrm{Hb}$ and reticulocyte values, is most commonly caused by infection, both bacterial and viral. Megaloblastic crisis is occasionally seen in those patients who become folate-deficient because of poor dietary habits and no folic acid supplementation. Iron deficiency anemia may complicate SCA, especially in young menstruating women who refuse blood transfusion if needed. Whether iron deficiency anemia has a salutary effect on the phenotypic expression of SCA because of impaired $\mathrm{Hb} \mathrm{S}$ polymerization secondary to decreased mean corpuscular hemoglobin concentration, or not, is an issue that is not settled in the literature. 


\section{Hyperviscosity}

Whole blood viscosity is a function of the number, deformability, and aggregability of erythrocytes, as well as of the quantity and nature of plasma proteins (see the review by Connes et al in this special issue of Clinical Hemorheology and Microcirculation). In SCD, viscosity is dominated by $\mathrm{Hb} \mathrm{S}$ gelation and the presence of dense sickle cells. The hyperviscosity syndrome in SCD (and other hemoglobinopathies) occurs most frequently post-transfusion [63].

\section{Transfusional Hemosiderosis}

Transfusional hemosiderosis or iron overload refers to an increase in total body iron due to multiple blood transfusions of $\geq 20$ units or $\geq 200 \mathrm{~mL} / \mathrm{kg}$ of red blood cells and serum ferritin level of $>1000 \mathrm{ng} / \mathrm{mL}$ and transferrin saturation $>50 \%$ on $\geq 3$ serial determinations in the steady state or measurement of abnormally increased iron by liver biopsy, magnetic resonance imaging (MRI) T2* or Ferriscan [64-66].

\section{Organ Damage/Failure}

Almost all organs are affected in SCD in general and SCA in particular. These were recently reviewed in a few publications [67-69]. The major systems affected and their management will be summarized below.

\section{Infection}

Sickle cell anemia has an unusual relationship to certain infectious agents. Individuals with sickle trait are resistant to infection by Plasmodium falciparum but patients with SCA are susceptible. Individuals with Fy (a-b-) RBC are resistant to infection by other types of malarial parasites. Several acquired abnormalities render patients with SCD immune compromised and, 
hence, susceptible to a number of infections that are a major cause of mortality and morbidity in these patients. The increased susceptibility of patients to infection with the polysaccharideencepsulated bacteria (S. pneumoniae and H. influenzae) is secondary to the absence of splenic function. Cellular immunity may be compromised by transfusion-related iron overload and abnormalities in B-cell immunity may explain antigen processing defects. Infections due to E. coli are usually associated with urinary tract infection in adult patients. Patients with SCA are susceptible to osteomyelitis secondary to $\mathrm{S}$. typhimurium in addition to the usual causes of bacterial osteomyelitis such as S. aureus. The susceptibility to infection by Salmonella may reflect the ability of this organism to flourish in partially necrotic bone [70].

\section{Neurological complications}

These include cerebrovascular accidents (strokes), transient ischemic attacks, silent infarcts and neurocognitive impairment. Cerebrovascular accidents include infarctive stroke mostly in children, hemorrhagic stroke mostly in adults and moyamoya. Infarctive stroke is an acute neurological syndrome resulting from impaired cerebral blood flow without evidence of hemorrhage lasting more than 24 hours. Hemorrhagic stroke is intracranial hemorrhage causing neurologic symptoms and signs. Moyamoya is abnormal vascular network ("puff of smoke" appearance) indicative of collateral circulation secondary to stenosis or occlusion of large cerebral arteries [71, 72].

Transient ischemic attack is a brief episode of neurologic dysfunction caused by focal brain ischemia, with clinical symptoms typically lasting less than 1 hour, and without subsequent evidence of cerebral infarction [71, 73]. Silent cerebral infarcts (SCI) are changes on MRI of brain consistent with infarction without associated history of neurologic symptoms or abnormal 
neurological exam $[71,74]$. Most SCI are localized in the deep white matter and less commonly in the subcortical grey matter structures. In the Comprehensive Study of SCD (CSSCD), about $25 \%$ of the children with SCI had new and/or enlarging lesions on follow-up MRI scan [75]. In comparison only $2.5 \%$ of the children without SCI, had new and/or enlarging lesions on followup MRI scan. The SIT trial showed that regular blood transfusion to children aged 5-14 years with SCI reduced the risk of reinfarction, both overt stroke and silent infarcts [76].

Neurocognitive impairment is defined by the presence of abnormal nonverbal function assessed by the Wechsler Adult Intelligence Scale III Performance IQ Index in adult patients with SCA who are neurologically asymptomatic. This impairment is most likely secondary to cerebral hypoxemia undetectable by standard neuroimaging studies $[77,78]$.

\section{Ophthalmological Complications}

The most important and serious ophthalmological complications of SCD include the following:

Proliferative sickle retinopathy which is neovascular fronds that emerge from the retinal vasculature at the interface of perfused and non perfused retina in response to vascular growth factors produced by ischemic retina. The neovascular tissue is predisposed to hemorrhage and vitreoretinal traction forces. Although these pre-retinal neovascular formations, which may resemble and are called sea fans, are bright red when viable, they appear white when autoinfarcted or caused to involute by laser photocoagulation [79].

Retinal detachment is separation of the retina from the choroid and eye wall due to holes in the retina and traction on the retina by vitreous bands and condensed pre-retinal membranes 
(usually as sequelae of proliferative sickle retinopathy). Retinal detachment is the most severe complication (Stage V) of proliferative sickle retinopathy [80].

Vitreous hemorrhage is bleeding into the vitreous cavity caused by mechanical stress (from trauma or normal vitreous movement) on the delicate neovascular fronds growing from the retina into the vitreous chamber. Vitreous hemorrhage is a severe complication of proliferative sickle retinopathy [81].

\section{Cardiac Complications}

High output failure, right heart and/or congestive heart failure, cardiac hemosiderosis and cardiomegaly are known manifestations of SCD. Recent evidence suggests that myocardial ischemia may occur as well and myocardial infarction has been reported [82]. Mitral valve prolapse was reported to have high prevalence (23\%) in SCD [83]. This finding, however, was not confirmed by another group [84]. The signs and symptoms of mitral valve prolapse (chest pain, fatigue, syncope, palpitations, etc.) overlap with those of SCD and may elucidate the protean manifestations of SCD in case there is an association between these two disorders.

\section{Pulmonary Complications}

\section{Acute Chest syndrome}

The incidence of ACS is age and genotype dependent, with no difference between sexes. It is approximately three times more common in young children than in adults but more severe in adults $[85,86]$. Acute chest syndrome is most common in SCA, sickle $\beta^{0}$-thalassemia, $\mathrm{Hb} \mathrm{SC}$ disease, and sickle $\beta^{+}$thalassemia in decreasing order of frequency. Coexistent $\alpha$-gene deletion, PLT count, and mean corpuscular volume of RBCs do not appear to affect the incidence of ACS 
[86]. The incidence of ACS decreases in the presence of high $\mathrm{Hb}$ F level and severe anemia but is directly proportional to the steady state white blood cell count [86]. Acute chest syndrome is closely associated with VOCs, especially in adults $[87,88]$. It occurs in approximately $50 \%$ of hospitalized patients with SCA for VOC [87, 89-91]. These episodes account for $15 \%$ of acute admissions and are potentially fatal [92-94]. Moreover, ACS appears to be the most common cause of death among patients and second to VOC as the most common cause of hospitalization of patients with SCD [95-98]. Although ACS is usually self-limited and resolves with treatment, it can be associated with respiratory failure, with a mortality rate of $1.8 \%$ in children and $4.8 \%$ in adults [87, 99].

Causes of ACS include pneumonia, bone marrow fat embolism, pulmonary infarct due to in situ sickling, rib/sternal infarction, infection, and pulmonary embolism (PE) (149-151). Approximately 50\% of patients with ACS have no identifiable etiology [87]. Pulmonary bone marrow fat embolism in patients with SCA appears to be more common than previously thought $[87,99]$. The characteristic clinical picture is that of severe bone pain, usually in long bones, followed by dyspnea, hypoxia and fever. Tissue infarction of the bone marrow within long bones appears to generate a source of fat and necrotic tissue that has been demonstrated in the lung on autopsy.

Diagnostic work-up should include serial chest radiographs, cultures of sputum and blood, monitoring of arterial blood gases and $\mathrm{Hb}$ level, ventilation and perfusion (V/Q) scans, analysis of induced sputum, bronchial washings, and analysis of urine for fat globules, and ruling out thrombophlebitis in the pelvis or lower extremities. The diagnosis of fat embolism entails the identification of fat-laden macrophages in induced deep sputum, or better by bronchoalveolar lavage fluid obtained by bronchoscopy $[87,100]$. 
The management of ACS involves multiple modalities to prevent possible catastrophic outcomes. The most important aspect of management is to maintain adequate ventilation. In mild cases, incentive spirometry may be sufficient to achieve this. However, in severe cases, mechanical ventilation in the intensive care unit is essential.

Once adequate ventilation is maintained, specific treatment includes oxygen, antibiotics, simple blood transfusion or exchange transfusion, judicious use of analgesics, bronchodilators, careful hydration, and possible vasodilators. Incentive spirometry prevents splinting and atelectasis and may actually prevent ACS in patients with rib infarction [101]. Intravenous antibiotics are indicated because it is difficult to rule out pneumonia or infected lung infarcts.

A combination of a third-generation cephalosporin and a macrolide or a quinolone antibiotic should be used to cover typical and atypical pathogens. Simple transfusion or exchange transfusion is indicated in patients with worsening respiratory function. The beneficial effects of blood transfusion may not be due simply to decreasing the proportion of sickled RBCs; other mechanisms may be involved. These include (1) an immunomodulatory mechanism by which inflammatory cytokines (interleukin [IL]-8 in particular) bind to the Duffy antigen present on transfused RBCs but often absent on RBCs of Africans and African Americans [102]; and (2) the albumin that is present in transfused units or used in blood exchange may bind free fatty acids, thus neutralizing their damaging effect on the pulmonary endothelium.

\section{Pulmonary Hypertension}


Pulmonary hypertension is increased blood pressure in the pulmonary vasculature (both micro \& macro vasculature). Clinical picture includes dyspnea, palpitations, pain (chest and abdomen), syncope, cyanosis, edema, fatigue and heart failure. The World Health Organization (WHO) classifies pulmonary hypertension into five groups. Among these the pulmonary arterial hypertension $(\mathrm{PAH})$ and the pulmonary venous hypertension $(\mathrm{PVH})$ are the most common and most important in SCD.

The pathophysiology of PAH includes two mechanisms: vascular obstruction and intimal hyperplasia. The vasoconstriction is due to decreased nitric oxide bioavailability and increased production of vaso-constrictors such as endothelin [103]. Intimal hyperplasia is the result of the hypoxia response pathway [104]. Specifically, hypoxia induced factors $\alpha$ and $\beta$ (HIF- $\alpha$ and HIF$\beta$ ) translocate to the nucleus across the cell membrane. The $\alpha / \beta$ complex activates the transcription of genes that increase cell proliferation and inflammation thus causing intimal hyperplasia and vaso-occlusion. The PVH, on the other hand, is due to left ventricular failure.

Pulmonary hypertension is technically defined by a mean pulmonary artery pressure (MPAP) $\geq 25 \mathrm{mmHg}$ which can be determined by echocardiography. In order to determine whether it is PAH or PVH, however, depends on the mean pulmonary capillary wedge pressure which cannot be determined by echocardiography but requires right heart catheterization (RHC). PAH is characterized by MPAP $\geq 25 \mathrm{mmHg}$ and capillary wedge pressure $\leq 15 \mathrm{mmHg}$ whereas in PVH the capillary wedge pressure is $>15 \mathrm{mmHg}$.

Treatment of pulmonary hypertension depends on its etiology. Thus the treatment of PVH targets the management of left ventricular failure. Treatment of PAH includes the use of vasodilators. This worked in PAH in the general population but not in PAH in patients with 
SCD. For now management of PAH in SCD includes blood transfusion and HU. More studies and controlled trials are needed to determine the appropriate treatment of the PAH of SCD.

\section{Genitourinary Complications}

Table 2 lists the major genitourinary manifestations of SCD. Urinary tract infection is usually caused by E. coli and is more common in females than in males. Its increased frequency in SCD may relate to renal infarction or immunodeficiency. The hypoxic, acidotic and hypertonic microenvironment of renal medulla causes sickling of red cells in the vasa recta leading to infarction of the renal medulla, hyposthenuria and hematuria (gross or microscopic). Inability to acidify the urine after an acid load can also occur. These tubular defects of the kidney (hematuria, hyposthenuria) occur not only in patients homozygous for the sickle gene, but in heterozygotes as well (AS, SC, SD, SO, etc.). Hematuria may be due to acute renal papillary necrosis, urinary tract infection, and less commonly to glomerulonephritis, obstruction, analgesic toxicity, mycobacterial infection, nephrolithiasis, tumor (renal cell carcinoma or medullary cell carcinoma), arterio-venous malformations, and vasculitis [105]. Hematuria, especially gross hematuria, may be the first sign of renal medullary carcinoma. Enuresis occurs in children. Potassium excretion is also impaired and episodes of hyperchloremia acidosis have been reported. Papillary necrosis seems to be more common in $\mathrm{Hb} \mathrm{SC}$ disease. Hyperuricemia in SCA is due to increased marrow activity with consequent enhanced purine metabolism and to an acquired defect in the renal tubules. Gout has been described in a few patients.

Nephrotic syndrome occurs infrequently with or without hypertension. Microscopic hematuria, proteinuria, hypertension and the nephrotic syndrome are markers of incipient endstage renal failure. The pathologic lesion is usually glomerulosclerosis. Once chronic renal 
failure sets in, patients require chronic hemodialysis and are candidates for kidney transplantation.

Acute renal failure is characterized by an abrupt decline in renal function resulting in an inability to excrete metabolic wastes and maintain proper fluid and electrolyte balance [106, 107]. Chronic renal failure is an irreversible and usually progressive reduction in renal function in which both kidneys have been damaged to the extent that they are unable to adequately remove the metabolic products from the blood and regulate the body's electrolyte composition and acid-base balance. End stage renal disease (ESRD) is the final stage in chronic renal insufficiency and, by definition, requires dialysis or renal transplantation to prevent death [108].

\section{Priapism}

Priapism occurs when sickle cells congest the corpora and prevent emptying of blood from the penis. It is a common complication of SCD, affecting 35\% of boys and men [109]. It is most common in patients with SCA, who account for approximately $80 \%$ to $90 \%$ of reported cases [110-113]. However, it does occur in males with all forms of SCD including Hb SC disease, all types of sickle thalassemia, and in those with sickle trait $[110,114]$. In one survey, a single episode of priapism was reported by $31 \%$ to $64 \%$ of patients, mostly children; approximately $50 \%$ of all patients had recurrent episodes, from 2 to 50 times or more, and the estimated mean duration of an episode was 125 minutes (range 50-480 minutes) [112, 113, 115, 116]. Priapism is not unique to SCD; it could be secondary to trauma, infection, neoplasm, hemoglobinopathies other than SCD, polycythemia, other hemolytic disorders, or hematologic malignancies [117121]. 
Clinically, priapism may be stuttering, minor, or major. Stuttering priapism is the occurrence of short, repetitive, and reversible painful episodes with detumescence occurring within a few hours after the onset of erection. This pattern has a good prognosis and is associated with normal sexual function and rarely requires medical intervention. The prevalence of stuttering priapism varies from approximately $2 \%$ of men with SCD according to some investigators [113] to $40 \%$ to $60 \%$ of men and boys with SCD according to others $[115,122]$.

Management of priapism is highly controversial. Controlled studies are lacking, therapeutic approaches are controversial and often conflicting, and medical and surgical therapies fail in most patients. Minor episodes of priapism and stuttering priapism usually last less than 4 hours and are often treated at home with analgesics, benzodiazepines, or pseudoephedrine and do not require treatment at the ED or hospital. Patients are advised to report to the ED if an episode lasts longer than 4 hours. Initial treatment in the ED should include hydration and opioid analgesics. Catheterization of the urinary bladder may be indicated to promote emptying. If these measures fail to cause detumescense, penile aspiration and epinephrine irrigation should be performed. Mantadakis et al. [123] recommend that aspiration of blood from the corpora cavernosa, followed by irrigation with dilute epinephrine, should be the initial therapy used for patients with SCA and prolonged priapism.

Simple transfusion or exchange transfusion may be performed for patients whose priapism does not respond to aspiration and irrigation procedures and persists for 24 hours or longer [124-126]. An association between blood exchange transfusion for priapism due to SCD and severe neurologic events including severe headache, seizures, focal neurological deficits, and obtundation has been made $[127,128]$. This association has been named the ASPEN syndrome (Association of Sickle cell disease, Priapism, Exchange transfusion, and Neurologic events). 
However, analysis of their data shows that the $\mathrm{Hb}$ level after blood exchange was much greater than the patient's baseline level. Thus, the neurologic complications were most likely due to transfusion- induced hyperviscosity. A larger study of blood exchange transfusion in patients with priapism, which maintained the post-exchange $\mathrm{Hb}$ level similar to baseline values, showed no neurologic complication in any of the patients [129]. Patients responding to transfusion therapy usually experience detumescence within 24 to 48 hours after the procedure. If detumescense does not occur within 24 hours after the completion of blood exchange transfusion, surgical intervention should be considered. Surgical intervention includes various shunt procedures between the cavernosa and the spongiosum $[130,131]$. Without intervention, severe priapism results in impotence in $>80 \%$ of patients. The combination of transfusions and surgery can decrease this to $25 \%$ to $50 \%$. Patients who become impotent may benefit from psychologic counseling and the insertion of a prosthetic penile implant.

\section{Hepatobiliary Complications}

Hepatic sequestration is sequestration of red blood cells in hepatic sinusoids, leading to liver enlargement and decreased $\mathrm{Hb}$ concentration by $\geq 2 \mathrm{~g} / \mathrm{dL}$ from baseline with reticulocytosis, without other explanation and liver enlargement of $\geq 3 \mathrm{~cm}$ for children and $\geq 5 \mathrm{~cm}$ for adults (from previous physical examination) without other explanation [132, 133]. Intrahepatic cholestasis is intrahepatic obstruction of bile formation or flow leading to hyperbilirubinemia. In $\mathrm{SCD}$, this syndrome may occur in the context of hepatic sequestration with the addition of striking hepatic dysfunction with marked increase in direct bilirubin ( $>50 \%$ of total) compared to baseline and absence of extrahepatic biliary system obstruction and absence of evidence of marked accelerated hemolysis [134]. 
Viral hepatitis (Hepatitis B or C) is usually a consequence of chronic blood transfusion therapy. The right upper quadrant (RUQ) syndrome refers to patients with SCD who present with pain in the RUQ. Differential diagnosis of this entity includes VOC, cholecystitis, acute hepatic sequestration and intrahepatic cholestasis (hepatic crisis).

\section{Musculoskeletal/Dermatologic Complications}

Dactylitis (hand-foot syndrome) is inflammation caused by ischemia/ infarction of bone and/or bone marrow of the hands and/or feet, resulting in swelling, redness, and pain in affected areas. One of the earliest manifestations of SCD, dactylitis is seen primarily in children from 6 months to 3 years of age, and generally does not occur beyond 5 years of age, due to the lack of hematopoietic marrow activity in the hands and feet [135].

Avascular necrosis (AVN) and leg ulcers were described above in the pain syndromes section.

\section{Acute Multiorgan Failure (MOF)}

This is a catastrophic life threatening complication of SCD in the context of VOC that may even occur in patients with otherwise mild SCD [136]. Fever, rapid decrease in Hb level and PLT count, nonfocol encephalopathy and rhabdomyolysis are associated with MOF. Prompt and aggressive simple blood transfusion or blood exchange transfusion could be lifesaving with rapid recovery of organ failure in most cases MOF may occur in patients with history of relatively mild disease with little or no evidence of chronic organ damage and may be recurrent. High $\mathrm{Hb}$ levels in the steady state may be a predisposing factor. 
Differential diagnosis of MOF includes ACS and drug overdose. MOF is initially heralded by a rapid fall in $\mathrm{Hb}$ and PLT counts from baseline. Aspartate aminotransferase (AST), alanine aminotransferase (ALT), total and direct bilirubin, serum creatinine, and CPK are elevated by the third or fourth day of a VOC.

\section{Management of Sickle Cell Disease}

Management of SCD in general and its complications in particular follow five major approaches (Table 3). These include supportive management, symptomatic treatment, preventative management, abortive, and curative approaches to management. Although these approaches apply to the disease as a whole, at least one of them applies to each complication as well.

\section{Supportive Management}

The approach to supportive management is to maintain the essential requirements for good health and good quality of life including balanced diet, no obesity, no smoking, minimum or no alcohol, no illicit drugs, sleep, hydration, adherence to medical plans and folic acid. Oral hydration should be with water not soft drinks.

\section{Symptomatic Management}

The goal of symptomatic management is to alleviate the symptoms of the disease as they occur. These include: 1) management of pain with nonpharmacologic and/or pharmacologic approaches. The latter include opioids, non-opioids and adjuvants. Opioids used are usually short-acting for acute pain and long-acting or with extended or sustained release \pm short-acting for chronic pain; it is important to note that the current national opioid phobia in the USA may, 
unwittingly, deny opioids to patients who really need them, especially those patients who experience recurrent episodes of acute pain such as patients with SCD who are innocent bystanders guilty by association within the frame of the current opioid epidemic; 2) RBC transfusion for severe anemia, aplastic crisis, acute chest syndrome, acute stroke, multi-organ failure, and for the prevention of primary and secondary strokes. Blood transfusion could be simple or exchange depending on the nature of the clinical complication; 3) antibiotics for prophylaxis or for the treatment of infections; 4) Psycho-social supports as needed.

\section{Preventative Management}

The goal of preventive therapy is to ameliorate the clinical picture of SCD in general and to decrease the frequency and severity of VOCs in particular. For many years, the major goal of primary therapy for SCD was to identify an anti-sickling agent that would prevent or reverse the polymerization of sickle $\mathrm{Hb}$ in RBCs. Sodium cyanate inhibits polymerization of $\mathrm{Hb} \mathrm{S}$ in vitro but is not beneficial in vivo at levels that provide acceptable toxicity [137]. The use of sodium cyanate was associated with peripheral neuropathy and subcapsular cataracts, which prevented its use as an antisickling agent. Although the search for beneficial antisickling compounds continues, the most promising approaches to prevent the frequency and severity of VOCs include the prevention of infection (including antibiotic prophylaxis in infancy and childhood), vaccination, avoidance of stressful situations, induction of Hb F production, blood transfusion, anti-adhesion therapy and many agents that await confirmation of benefit in clinical trials.

\section{Fetal Hemoglobin (Hb F) Induction}

High levels of $\mathrm{Hb} \mathrm{F}$ have a beneficial effect in patients with SCA. Platt et al. [15] demonstrated a significant inverse correlation between the frequency of VOCs and Hb F levels 
greater than 4\%; the higher $\mathrm{Hb} \mathrm{F}$ level, the milder the disease. Hemoglobin $\mathrm{F}$ interferes with the polymerization of $\mathrm{Hb} \mathrm{S}$; the higher (and the more pancellular) the $\mathrm{Hb} \mathrm{F}$ level, the lower the intracellular concentration of $\mathrm{Hb} \mathrm{S}$. Exceptions to this rule include some patients with high $\mathrm{Hb} \mathrm{F}$ level and severe disease and vice versa.

Among the agents that increase the level of $\mathrm{Hb} F$ in humans these, hydroxyurea (HU) as monotherapy seems to be the least toxic and most effective $[34,35,138]$. Moreover, HU is the only drug studied for efficacy in a relatively large scale, placebo-controlled, randomized clinical trial. All the other agents such as decitabine, arginine butyrate, valproic acid, etc. have been reported anecdotally to increase $\mathrm{Hb} \mathrm{F}$ levels. None of the others was used in a controlled phase III clinical trial to date.

\section{Hydroxyurea}

The molecular mechanism(s) by which $\mathrm{HU}$ increases the production of $\mathrm{Hb} \mathrm{F}$ is (are) unknown. Possible mechanisms include perturbations in cellular kinetics and/or recovery from cytotoxicity, recruitment of early erythroid progenitors and recruitment of primitive erythroid progenitors (BFU-E) that lead to production of $\mathrm{Hb}$ F-containing reticulocytes (F-reticulocytes). Long-term HU therapy with the maximum tolerated dose (mean dose $21.3 \mathrm{mg} / \mathrm{kg}$ ) with respect to myelosuppression raises $\mathrm{Hb} \mathrm{F}$ by as much as $15 \%$ to $20 \%$ (mean $14.9 \%$, range $1.9 \%$ to $26.3 \%$ ).

In the randomized, placebo-controlled, double blind Multi-center Study of Hydroxyurea (MSH) in SCA, among 299 adult patients with SCA with three or more VOCs per year, HU resulted in a significant $(\mathrm{p}<0.001)$ reduction in the incidence of VOCs, ACS, and transfusion requirement [34, 35]. Hydroxyurea improved the quality of life of the patients taking it [139]. There was no difference between the placebo and HU arms in the incidence of death, stroke, or 
hepatic sequestration. Maximum tolerated doses of $\mathrm{HU}$ were not required to reduce the incidence of VOCs. Although an increase in $\mathrm{Hb} \mathrm{F}$ seems to be the obvious and logical explanation for the salutary effects of HU, other reasons for its beneficial effects include changes in RBC volume, cellular hydration, the cell membrane, and a direct effect on endothelial cells.

\section{Hydroxyurea and the HUG Trials}

The success of MSH prompted pediatricians to follow suit and determine the efficacy of HU in children. A multicenter Phase I/II trial of HU in children with SCA (HUG-KIDS) showed that HU therapy is safe for children with SCA when treatment is directed by a pediatric hematologist. Treatment of children with HU induced similar laboratory changes as in adults, and children could tolerate doses of HU as high as $30 \mathrm{mg} / \mathrm{kg} / \mathrm{day}$ [140].

Another 2-year, prospective, multicenter, open-label, single-arm, pilot study (Hydroxyurea Safety and Organ Toxicity [HUSOFT]) of HU in very young children with SCA showed that HU treatment for infants with SCA is feasible and well tolerated, has hematologic efficacy, and may delay functional asplenia [141]. An extension study of the HUSOFT trial, in which the dose of HU was increased to up to $30 \mathrm{mg} / \mathrm{kg} /$ day, showed that infants with SCA tolerated prolonged HU therapy, with sustained hematologic benefits, fewer ACS events, and possibly preserved organ function [142]. These early studies in infants and children led to the Pediatric Hydroxyurea Phase III Clinical Trial (BABY HUG).

The main objective of BABY HUG was to determine if HU can prevent the onset of chronic end-organ damage in young children with SCA [143]. The primary endpoints of the study were splenic function (determined by qualitative uptake on 99Tc spleen scan) and renal function (determined by glomerular filtration rate by $99 \mathrm{mTc}$-diethylene triamine pentaacetic acid 
[DTPA] clearance). Other endpoints included blood counts, Hb F, chemistry profiles, spleen function biomarkers, urine osmolality, neurodevelopment, transcranial Doppler ultrasonography, growth, and mutagenicity [143]. A total of 96 patients received HU, and 97 patients received placebo. The study confirmed the safety and efficacy of HU therapy for infants with SCA. However, treatment with HU showed no significant differences for the primary endpoints: splenic function, or glomerular filtration rate [144].

A different prospective HU study of long-term effects (HUSTLE) showed that HU at maximum tolerated dose is associated with a decrease in hyperfiltration in young children with SCA [145]. In the BABY HUG trial, treatment with HU was associated with decreased pain (177 events in 62 patients on $\mathrm{HU}$ vs 375 events in 75 patients in the placebo group, $\mathrm{P}=0.002$ ), decreased dactylitis (24 events in 14 patients on HU vs 123 events in 42 patients in the placebo group, $\mathrm{P}<0.0001$ ), and decreased incidence of ACS, hospitalizations, and blood transfusions [143]. Treatment with $\mathrm{HU}$ increased $\mathrm{Hb}$ and $\mathrm{Hb} \mathrm{F}$ and improved hematologic values, decreased white blood cell count, and perhaps increased preservation of organ function $[143,146]$.

Toxicity was limited to mild to moderate neutropenia. The TCD with Transfusions Changing to Hydroxyurea (TWiTCH) trial showed that the transition of pediatric patients from transfusion to HU was safe if they met the criteria of the study [147]. Whether this would be the same in adults remains to be seen.

Most recently, a phase 3 randomized clinical trial of L-glutamine powder in getting patients with SCA age 5 years and older demonstrated its safety and efficacy in reducing the frequency of VOCs that lead to approval by the FDA [148]. The mechanism of action of Lglutamine is the reduction of oxidative stress in sickle RBC resulting in decreased $\mathrm{RBC}$ 
adhesion, decreased vasoocclusion, and thus, fewer VOCs. Fewer VOCs, in turn, translate into decreased mortality in SCD.

\section{Other Novel Approaches to Therapy}

A large number of novel preventive therapeutic modalities may have promising roles in the management of SCD in general and sickle cell pain in particular. These include, among other things, anti-adhesion molecules [149], surfactants [150], levocarnitine, zileuton (a 5lipoxygenase inhibitor), green tea [151], aged garlic [151], and herbal extracts [152]. Some of these agents are being used on an investigational basis. There are anecdotal reports of success in a few patients using some of these agents. However, the efficacy of any of these agents awaits proof in Phase III, randomized, double-blind, placebo-controlled trials. Such trials will determine if a certain drug is safe, efficacious, and capable of improving the quality of life of treated patients. Recently, Singh and Ballas reviewed about 38 drugs that were tried or about to be tried in several clinical trials for the prevention of VOCs and related complications [153]. As mentioned above, the Phase III trial of senicapoc was terminated because patients who took senicapoc had more VOCs than control subjects. A Phase III trial of sildenafil to treat patients with elevated tricuspid regurgitant velocity and low exercise capacity was terminated for the same reason [154].

\section{Abortive management}

The major purpose of this approach is to abort painful VOCs thus preventing them from getting worse or precipitating other complications. In a sense, HU achieved this partially by reducing the length of hospital stay by 2 days compared to the placebo group [155]. Nitric oxide aborted VOCs in the ED but not in hospitalization $[156,157]$. 


\section{Curative Therapies}

\section{Allogeneic Hematopoietic Stem Cell Transplant}

The only curative therapy available at present for SCD in general, and SCA in particular, is stem cell transplant. In 1998, 70 patients with SCA had undergone bone marrow transplant worldwide. By the end of the 20th century, at least 100 patients with SCA had undergone transplant worldwide [158-161]. At that time, most patients were children who received bone marrow allografts from siblings with identical human leukocyte antigen (HLA) match and who underwent myeloablative conditioning. Although the estimated risk of mortality from HLAidentical bone marrow transplant was relatively low $(\sim 5 \%)$, there was some concern regarding short-term and long-term toxicity, lack of availability of suitable donors, and barriers to wider application [162]. Nevertheless, an interim report on the impact of bone marrow transplant for symptomatic SCD found that allogeneic bone marrow transplant establishes normal erythropoiesis and is associated with increased growth and stable central nervous system imaging results and pulmonary function in most patients [158]. Things have changed for the better since 2000; some of the barriers have been overcome, and more patients are awaiting appropriate donors for transplant. The advent of high-resolution HLA typing, the choice of stem cell sources (bone marrow, peripheral blood or cord blood), less toxic conditioning regimens, new immunosuppressive agents, facilitated immune reconstitution, and improved supportive care have made transplant a more viable option for patients with SCD [163-167]. By 2010, less than 500 patients with SCD who have undergone transplant have been reported in the Center for International Blood and Marrow Transplant Research database [163]. 
Allogeneic hematopoietic stem cell transplant is the only curative treatment for SCD at present. It is successful in approximately $90 \%$ of patients. Unfortunately, conventional approaches to transplant are associated with comorbidities including, among other complications, infertility, gonadal failure, and chronic Graft Versus Host Disease (GVHD). The use of umbilical cord blood has been shown to be as effective as, and possibly safer than, traditional bone marrow transplant in children with SCD. The use of nonmyeloablative conditioning regimens induce mixed chimerism in transplant recipients, resulting in decreased complications of allogeneic hematopoietic stem cell transplant in adults [168-170].

\section{Gene Therapy}

Although allogeneic bone marrow transplant can cure SCD, its widespread use is limited by the availability of suitable donors and by the complication of GVHD. Gene therapy is an alternative approach to achieve a cure of SCD. In simple terms, gene therapy is the introduction of normal genes into abnormal cells, either in vitro or in vivo. One potential approach to cure SCA is to introduce a functional $\beta^{\mathrm{A}}$-globin gene into hematopoietic stem cells of the affected individual to replace the abnormal $\beta^{\mathrm{S}}$-globin gene [171]. Methods to achieve this goal include the following:

- Targeted insertion of the transferred gene into the endogenous globin locus by homologous recombination, such that the transferred $\beta^{\mathrm{A}}$-globin gene is located in the proper chromosomal environment and expressed at the same level as endogenous $\beta$-globin. This would be the ideal approach, but it is not yet feasible in hematopoietic stem cells. 
- Chimeroplasty or gene repair, which introduces chimeric oligonucleotides composed of DNA and modified RNA residues into stem cells to direct correction of the mutation in the $\beta^{\mathrm{S}}$ gene [172].

- $\quad$ Transfer of normal $\beta^{\mathrm{A}}$-globin gene into hematopoietic cells via retroviral vectors that have been modified such that they do not become infective.

Recent years have witnessed significant progress in the third method mentioned above. Basically, this is stem cell gene transfer or autologous transplant, in which the patient's own stem cells are harvested from the bone marrow or peripheral blood, genetically modified, and transplanted back into the patient. Genetic modification involves the use of vectors carrying $\gamma$ globin genes for SCD or $\beta$-globin genes for $\beta$-thalassemia. This approach has already been established in mice and was successful in a Phase I/II study, with anticipated benefit for $\mathrm{Hb}$ disorders. Successful conversion of a patient with $\beta$-thalassemia major to transfusion independence has been reported [169, 173-176].

\section{Conclusion}

Although management of SCA continues to be primarily palliative in nature, there have been promising preventative and curative approaches to therapy. Pain management should be individualized and coupled with the proper utilization of opioid and nonopioid analgesics in order to achieve adequate pain relief. Early recognition and treatment of organ failure minimizes morbidity and improves outcome. The use of HU decreases the morbidity and mortality of SCD. Cure is possible in selected children and young adults with bone marrow, stem cell or cord blood transplantation. Future research seems to focus on refining the molecular and cellular approaches 
to therapy including gene therapy and mechanisms that prevent the adhesion of sickle RBC to vascular endothelium.

\section{Legend to Figure 1}

Sequence of complications of SCA from birth through adult life. Cure is possible in selected patients. The mainstay of management in most patients is palliative, with pain management being most important. ACS, acute chest syndrome; AVN, avascular necrosis; CVA, cerebrovascular accident. (Modified from Ballas SK. Sickle cell disease: current clinical management. Semin Hematol 2001;38(4):308; with permission).

\section{References}

[1] Neel J. The inheritance of the sickling phenomenon with particular reference to sickle cell disease. Blood. 1951;6:389-412.

[2] Ingram V. A specific chemical difference between the globins of normal human and sickle-cell anemia haemoglobin. Nature. 1956;178:792-4.

[3] Ingram VM. Gene mutations in human haemoglobin: the chemical difference between normal and sickle cell haemoglobin. Nature. 1957;180(4581):326-8.

[4] Farrell K, Dent L, Nguyen ML, Buchowski M, Bhatt A, Aguinaga Mdel P. The relationship of oxygen transport and cardiac index for the prevention of sickle cell crises. J Natl Med Assoc. 2010;102(11):1000-7.

[5] Telfer P, Coen P, Chakravorty S, Wilkey O, Evans J, Newell H, et al. Clinical outcomes in children with sickle cell disease living in England: a neonatal cohort in East London. Haematologica. 2007;92(7):905-12.

[6] Quinn CT, Rogers ZR, McCavit TL, Buchanan GR. Improved survival of children and adolescents with sickle cell disease. Blood. 2010;115(17):3447-52.

[7] Artz N, Whelan C, Feehan S. Caring for the adult with sickle cell disease: results of a multidisciplinary pilot program. J Natl Med Assoc. 2010;102(11):1009-16.

[8] Platt OS, Brambilla DJ, Rosse WF, Milner PF, Castro O, Steinberg MH, et al. Mortality in sickle cell disease. Life expectancy and risk factors for early death. N Engl J Med. 1994;330(23):1639-44. 
[9] Powars DR, Chan LS, Hiti A, Ramicone E, Johnson C. Outcome of sickle cell anemia: a 4-decade observational study of 1056 patients. Medicine (Baltimore). 2005;84(6):36376.

[10] Steinberg MH, Embury SH. Alpha-thalassemia in blacks: genetic and clinical aspects and interactions with the sickle hemoglobin gene. Blood. 1986;68(5):985-90.

[11] Pagnier J, Mears JG, Dunda-Beklhodja O. Evidence for the multicenter origin of the sickle cell hemoglobin gene in Africa. Proc Natl Acad Sci U S A. 1984;81:1771-3.

[12] Powars DR. Sickle cell anemia: beta s-gene-cluster haplotypes as prognostic indicators of vital organ failure. Semin Hematol. 1991;28(3):202-8.

[13] Ballas SK, Larner J, Smith ED, Surrey S, Schwartz E, Rappaport EF. Rheologic predictors of the severity of the painful sickle cell crisis. Blood. 1988;72(4):1216-23.

[14] Baum KF, Dunn DT, Maude GH, Serjeant GR. The painful crisis of homozygous sickle cell disease. A study of the risk factors. Arch Intern Med. 1987;147(7):1231-4.

[15] Platt OS, Thorington BD, Brambilla DJ, Milner PF, Rosse WF, Vichinsky E, et al. Pain in sickle cell disease. Rates and risk factors. N Engl J Med. 1991;325(1):11-6.

[16] Ballas SK, Talacki CA, Rao VM, Steiner RM. The prevalence of avascular necrosis in sickle cell anemia: correlation with alpha-thalassemia. Hemoglobin. 1989;13(7-8):64955.

[17] Milner PF, Kraus AP, Sebes JI, Sleeper LA, Dukes KA, Embury SH, et al. Sickle cell disease as a cause of osteonecrosis of the femoral head. N Engl J Med. 1991;325(21):1476-81.

[18] Renoux C, Connes P, Nader E, Skinner S, Faes C, Petras M, et al. Alpha-thalassaemia promotes frequent vaso-occlusive crises in children with sickle cell anaemia through haemorheological changes. Pediatr Blood Cancer. 2017;64(8).

[19] Koshy M, Enstuah R, Koranda A. Leg ulcers in patients in sickle cell disease. Blood. 1989;74:1403-8.

[20] Ballas SK, Gay RN, Chehab FF. Is Hb A2 elevated in adults with sickle-alphathalassemia (beta(S)/beta(S); -alpha/-alpha)? Hemoglobin. 1997;21(5):405-50.

[21] Steinberg MH, Hsu H, Nagel RL, Milner PF, Adams JG, Benjamin L, et al. Gender and haplotype effects upon hematological manifestations of adult sickle cell anemia. Am J Hematol. 1995;48(3):175-81.

[22] Robertson KD, Wolffe AP. DNA methylation in health and disease. Nat Rev Genet. 2000;1(1):11-9.

[23] Fabry ME. Molecular genetics of the human globin genes. In: Steinberg M H, Forget BG, Higgs D R, Nagel RL, editors. Disorders of hemoglobin: genetics, pathophysiology and clinical management. Cambridge: Cambridge University Press; 2001. p. 910-40.

[24] Thein SL. Genetic modifiers of the beta-haemoglobinopathies. Br J Haematol. 2008;141(3):357-66.

[25] Ashley-Koch AE, Elliott L, Kail ME, De Castro LM, Jonassaint J, Jackson TL, et al. Identification of genetic polymorphisms associated with risk for pulmonary hypertension in sickle cell disease. Blood. 2008;111(12):5721-6.

[26] Sebastiani P, Solovieff N, Hartley SW, Milton JN, Riva A, Dworkis DA, et al. Genetic modifiers of the severity of sickle cell anemia identified through a genome-wide association study. Am J Hematol. 2010;85(1):29-35.

[27] Steinberg MH. SNPing away at sickle cell pathophysiology. Blood. 2008;111(12):54201. 
[28] Steinberg MH. Genetic etiologies for phenotypic diversity in sickle cell anemia. Scientific World Journal. 2009;9:46-67.

[29] Steinberg MH, Adewoye AH. Modifier genes and sickle cell anemia. Curr Opin Hematol. 2006;13(3):131-6.

[30] Steinberg MH, Sebastiani P. Genetic modifiers of sickle cell disease. Am J Hematol. 2012;87(8):795-803.

[31] Thein SL. Genetic modifiers of sickle cell disease. Hemoglobin. 2011;35(5-6):589-606.

[32] Ballas SK. Sickle Cell Pain. Seattle: IASP Press; 1998.

[33] Ballas SK, Delengowski A. Pain measurement in hospitalized adults with sickle cell painful episodes. Annals of clinical and laboratory science. 1993;23(5):358-61.

[34] Charache S, Terrin ML, Moore RD, Dover GJ, Barton FB, Eckert SV, et al. Effect of hydroxyurea on the frequency of painful crises in sickle cell anemia. Investigators of the Multicenter Study of Hydroxyurea in Sickle Cell Anemia. N Engl J Med. 1995;332(20):1317-22.

[35] Charache S, Barton FB, Moore RD, Terrin ML, Steinberg MH, Dover GJ, et al. Hydroxyurea and sickle cell anemia. Clinical utility of a myelosuppressive "switching" agent. The Multicenter Study of Hydroxyurea in Sickle Cell Anemia. Medicine. 1996;75(6):300-26.

[36] Ballas SK, Smith ED. Red blood cell changes during the evolution of the sickle cell painful crisis. Blood. 1992;79(8):2154-63.

[37] Ballas SK. The sickle cell painful crisis in adults: phases and objective signs. Hemoglobin. 1995;19(6):323-33.

[38] Lemonne N, Lamarre Y, Romana M, Mukisi-Mukaza M, Hardy-Dessources MD, Tarer $\mathrm{V}$, et al. Does increased red blood cell deformability raise the risk for osteonecrosis in sickle cell anemia? Blood. 2013;121(15):3054-6.

[39] Styles LA, Vichinsky EP. Core decompression in avascular necrosis of the hip in sicklecell disease. Am J Hematol. 1996;52(2):103-7.

[40] Neumayr LD, Aguilar C, Earles AN, Jergesen HE, Haberkern CM, Kammen BF, et al. Physical therapy alone compared with core decompression and physical therapy for femoral head osteonecrosis in sickle cell disease. Results of a multicenter study at a mean of three years after treatment. J Bone Joint Surg Am. 2006;88(12):2573-82.

[41] Saito S, Saito M, Nishina T, Ohzono K, Ono K. Long-term results of total hip arthroplasty for osteonecrosis of the femoral head. A comparison with osteoarthritis. Clin Orthop Relat Res. 1989(244):198-207.

[42] Hanker GJ, Amstutz HC. Osteonecrosis of the hip in the sickle-cell diseases. Treatment and complications. J Bone Joint Surg Am. 1988;70(4):499-506.

[43] Clarke HJ, Jinnah RH, Brooker AF, Michaelson JD. Total replacement of the hip for avascular necrosis in sickle cell disease. J Bone Joint Surg Br. 1989;71(3):465-70.

[44] Learmonth ID, Young C, Rorabeck C. The operation of the century: total hip replacement. Lancet. 2007;370(9597):1508-19.

[45] Ballas SK. Treatment of painful sickle cell leg ulcers with topical opioids. Blood. 2002;99(3):1096.

[46] Powars D, Chan LS, Schroeder WA. The variable expression of sickle cell disease is genetically determined. Semin Hematol. 1990;27(4):360-76.

[47] Serjeant G. Sickle cell disease, 2nd ed. Oxford: Oxford University Press; 1992. 
[48] Wilkinson EA. Oral zinc for arterial and venous leg ulcers. Cochrane Database Syst Rev. 2012;8:CD001273.

[49] Minniti CP, Eckman J, Sebastiani P, Steinberg MH, Ballas SK. Leg ulcers in sickle cell disease. Am J Hematol. 2010;85(10):831-3.

[50] Gilsanz F, Escalante F, Auray C, Olbes AG. Treatment of leg ulcers in beta-thalassaemia intermedia: use of platelet-derived wound healing factors from the patient's own platelets. Br J Haematol. 2001;115(3):710.

[51] Papanas N, Maltezos E. Benefit-risk assessment of becaplermin in the treatment of diabetic foot ulcers. Drug Saf. 2010;33(6):455-61.

[52] Minniti CP, Gorbach AM, Xu D, Hon YY, Delaney KM, Seidel M, et al. Topical sodium nitrite for chronic leg ulcers in patients with sickle cell anaemia: a phase 1 dose-finding safety and tolerability trial. Lancet Haematol. 2014;1(3):e95-e103.

[53] Marcelo D, Beatriz PM, Jussara R, Fabiana B. Tissue therapy with autologous dermal and epidermal culture cells for diabetic foot ulcers. Cell Tissue Bank. 2012;13(2):241-9.

[54] Casey G, van Rij A. Manuka honey and leg ulcers. N Z Med J. 1997;110(1045):216.

[55] Gethin G, Cowman S. Case series of use of manuka honey in leg ulceration. Int Wound J. 2005;2(1):10-5.

[56] Queiroz AM, Campos J, Lobo C, Bonini-Domingos CR, Cardoso G, Ballas SK. Leg amputation for an extensive, severe and intractable sickle cell anemia ulcer in a Brazilian patient. Hemoglobin. 2014;38(2):95-8.

[57] Maximo C, Olalla Saad ST, Thome E, Queiroz AM, Lobo C, Ballas SK. Amputations in Sickle Cell Disease: Case Series and Literature Review. Hemoglobin. 2016;40(3):150-5.

[58] Dissemond J. Medications. A rare cause for leg ulcers. Hautarzt. 2011;62(7):516-23.

[59] Kikuchi K, Arita K, Tateishi Y, Onozawa M, Akiyama M, Shimizu H. Recurrence of hydroxyurea-induced leg ulcer after discontinuation of treatment. Acta Derm Venereol. 2011;91(3):373-4.

[60] Nzouakou R, Bachir D, Lavaud A, Habibi A, Lee K, Lionnet F, et al. Clinical follow-up of hydroxyurea-treated adults with sickle cell disease. Acta Haematol. 2011;125(3):14552.

[61] Ballas SK, Darbari DS. Neuropathy, neuropathic pain, and sickle cell disease. Am J Hematol. 2013;88(11):927-9.

[62] Ballas SK, Marcolina MJ. Hyperhemolysis during the evolution of uncomplicated acute painful episodes in patients with sickle cell anemia. Transfusion. 2006;46(1):105-10.

[63] Johnson CS. Arterial blood pressure and hyperviscosity in sickle cell disease. Hematol Oncol Clin North Am. 2005;19(5):827-37.

[64] Ballas SK. Iron overload is a determinant of morbidity and mortality in adult patients with sickle cell disease. Semin Hematol. 2001;38(1 Suppl 1):30-6.

[65] Karam LB, Disco D, Jackson SM, Lewin D, McKie V, Baker RD, et al. Liver biopsy results in patients with sickle cell disease on chronic transfusions: poor correlation with ferritin levels. Pediatr Blood Cancer. 2008;50(1):62-5.

[66] St Pierre TG, Clark PR, Chua-anusorn W, Fleming AJ, Jeffrey GP, Olynyk JK, et al. Noninvasive measurement and imaging of liver iron concentrations using proton magnetic resonance. Blood. 2005;105(2):855-61.

[67] Expert Panel Report. Evidence-Based Management of Sickle Cell Disease Bethesda MD: National Heart, Lung, and Blood Institute; 2014 [Available from: http://www.nhlbi.nih.gov/health-pro/guidelines/sickle-cell-disease-guidelines/. 
[68] Yawn BP, Buchanan GR, Afenyi-Annan AN, Ballas SK, Hassell KL, James AH, et al. Management of sickle cell disease: summary of the 2014 evidence-based report by expert panel members. JAMA. 2014;312(10):1033-48.

[69] Piel FB, Steinberg MH, Rees DC. Sickle Cell Disease. N Engl J Med. 2017;377(3):305.

[70] Ballas SK. Sickle Cell Pain, 2nd Edition. Washington DC: International Association for the Study of Pain; 2014.

[71] Ohene-Frempong K, Weiner SJ, Sleeper LA, Miller ST, Embury S, Moohr JW, et al. Cerebrovascular accidents in sickle cell disease: rates and risk factors. Blood. 1998;91(1):288-94.

[72] Dobson SR, Holden KR, Nietert PJ, Cure JK, Laver JH, Disco D, et al. Moyamoya syndrome in childhood sickle cell disease: a predictive factor for recurrent cerebrovascular events. Blood. 2002;99(9):3144-50.

[73] Albers GW, Caplan LR, Easton JD, Fayad PB, Mohr JP, Saver JL, et al. Transient ischemic attack--proposal for a new definition. N Engl J Med. 2002;347(21):1713-6.

[74] Debaun MR, Derdeyn CP, McKinstry RC, 3rd. Etiology of strokes in children with sickle cell anemia. Ment Retard Dev Disabil Res Rev. 2006;12(3):192-9.

[75] Pegelow CH, Macklin EA, Moser FG, Wang WC, Bello JA, Miller ST, et al. Longitudinal changes in brain magnetic resonance imaging findings in children with sickle cell disease. Blood. 2002;99(8):3014-8.

[76] DeBaun MR, Gordon M, McKinstry RC, Noetzel MJ, White DA, Sarnaik SA, et al. Controlled trial of transfusions for silent cerebral infarcts in sickle cell anemia. N Engl J Med. 2014;371(8):699-710.

[77] Vichinsky EP, Neumayr LD, Gold JI, Weiner MW, Rule RR, Truran D, et al. Neuropsychological dysfunction and neuroimaging abnormalities in neurologically intact adults with sickle cell anemia. JAMA. 2010;303(18):1823-31.

[78] Ballas SK. Neurocognitive complications of sickle cell anemia in adults. JAMA : the journal of the American Medical Association. 2010;303(18):1862-3.

[79] Goldberg MF. Classification and pathogenesis of proliferative sickle retinopathy. Am J Ophthalmol. 1971;71(3):649-65.

[80] Brazier DJ, Gregor ZJ, Blach RK, Porter JB, Huehns ER. Retinal detachment in patients with proliferative sickle cell retinopathy. Trans Ophthalmol Soc U K. 1986;105 ( Pt 1):100-5.

[81] Dana MR, Werner MS, Viana MA, Shapiro MJ. Spontaneous and traumatic vitreous hemorrhage. Ophthalmology. 1993;100(9):1377-83.

[82] Martin CR, Cobb C, Tatter D, Johnson C, Haywood LJ. Acute myocardial infarction in sickle cell anemia. Arch Intern Med. 1983;143(4):830-1.

[83] Lippman SM, Abergel RP, Ginzton LE, Uitto J, Tanaka KR, Miyamoto EK, et al. Mitral valve prolapse in sickle cell disease: manifestation of a generalized connective tissue disorder. Am J Hematol. 1985;19(1):1-12.

[84] Simmons BE, Santhanam V, Castaner A, Rao KR, Sachdev N, Cooper R. Sickle cell heart disease. Two-dimensional echo and Doppler ultrasonographic findings in the hearts of adult patients with sickle cell anemia. Arch Intern Med. 1988;148(7):1526-8.

[85] Vichinsky EP, Styles LA, Colangelo LH, Wright EC, Castro O, Nickerson B. Acute chest syndrome in sickle cell disease: clinical presentation and course. Cooperative Study of Sickle Cell Disease. Blood. 1997;89(5):1787-92. 
[86] Castro O, Brambilla DJ, Thorington B, Reindorf CA, Scott RB, Gillette P, et al. The acute chest syndrome in sickle cell disease: incidence and risk factors. The Cooperative Study of Sickle Cell Disease. Blood. 1994;84(2):643-9.

[87] Vichinsky EP, Neumayr LD, Earles AN, Williams R, Lennette ET, Dean D, et al. Causes and outcomes of the acute chest syndrome in sickle cell disease. National Acute Chest Syndrome Study Group. N Engl J Med. 2000;342(25):1855-65.

[88] Styles LA, Schalkwijk CG, Aarsman AJ, Vichinsky EP, Lubin BH, Kuypers FA. Phospholipase A2 levels in acute chest syndrome of sickle cell disease. Blood. 1996;87(6):2573-8.

[89] Vichinsky EP, Lubin BH. Sickle cell anemia and related hemoglobinopathies. Pediatr Clin North Am. 1980;27(2):429-47.

[90] Sprinkle RH, Cole T, Smith S, Buchanan GR. Acute chest syndrome in children with sickle cell disease. A retrospective analysis of 100 hospitalized cases. Am J Pediatr Hematol Oncol. 1986;8(2):105-10.

[91] Ashcroft MT, Serijant GR. Growth, morbidity, and mortality in a cohort of Jamaican adolescents with homozygous sickle cell disease. West Indian Med J. 1981;30(4):197201.

[92] Athanasou NA, Hatton C, McGee JO, Weatherall DJ. Vascular occlusion and infarction in sickle cell crisis and the sickle chest syndrome. J Clin Pathol. 1985;38(6):659-64.

[93] Barrett-Connor E. Acute pulmonary disease and sickle cell anemia. Am Rev Respir Dis. 1971;104(2):159-65.

[94] Davies SC, Luce PJ, Win AA, Riordan JF, Brozovic M. Acute chest syndrome in sicklecell disease. Lancet. 1984;1(8367):36-8.

[95] Gill FM, Sleeper LA, Weiner SJ, Brown AK, Bellevue R, Grover R, et al. Clinical events in the first decade in a cohort of infants with sickle cell disease. Cooperative Study of Sickle Cell Disease. Blood. 1995;86(2):776-83.

[96] Thomas AN, Pattison C. Causes of death in sickle-cell disease in Jamaica. Br Med J. 1982;285(6342):633-5.

[97] van Agtmael MA, Cheng JD, Nossent HC. Acute chest syndrome in adult AfroCaribbean patients with sickle cell disease. Analysis of 81 episodes among 53 patients. Arch Intern Med. 1994;154(5):557-61.

[98] Vichinsky EP. Comprehensive care in sickle cell disease: its impact on morbidity and mortality. Semin Hematol. 1991;28(3):220-6.

[99] Claster S, Vichinsky E. Acute chest syndrome in sickle cell disease: pathophysiology and management. J Intensive Care Med. 2000;15:59-66.

[100] Vichinsky E, Williams R, Das M, Earles AN, Lewis N, Adler A, et al. Pulmonary fat embolism: a distinct cause of severe acute chest syndrome in sickle cell anemia. Blood. 1994;83(11):3107-12.

[101] Rucknagel DL, Kalinyak KA, Gelfand MJ. Rib infarcts and acute chest syndrome in sickle cell diseases. Lancet. 1991;337(8745):831-3.

[102] Abboud MR, Taylor EC, Habib D, Dantzler-Johnson T, Jackson SM, Xu F, et al. Elevated serum and bronchoalveolar lavage fluid levels of interleukin 8 and granulocyte colony-stimulating factor associated with the acute chest syndrome in patients with sickle cell disease. Br J Haematol. 2000;111(2):482-90.

[103] Gaine S. Pulmonary hypertension. JAMA. 2000;284(24):3160-8.

[104] Simon MC. The Hypoxia Response Pathways - Hats Off! N Engl J Med. 2016. 
[105] Johnson C. Renal complications of the sickle cell diseases. Hematology Am Soc Hematol Educ Program.1999:44-50.

[106] Bellomo R, Ronco C, Kellum JA, Mehta RL, Palevsky P. Acute renal failure - definition, outcome measures, animal models, fluid therapy and information technology needs: the Second International Consensus Conference of the Acute Dialysis Quality Initiative (ADQI) Group. Crit Care. 2004;8(4):R204-12.

[107] Lameire N, Van Biesen W, Vanholder R. Acute renal failure. Lancet. 2005;365(9457):417-30.

[108] West MS, Wethers D, Smith J, Steinberg M. Laboratory profile of sickle cell disease: a cross-sectional analysis. The Cooperative Study of Sickle Cell Disease. J Clin Epidemiol. 1992;45(8):893-909.

[109] Olujohungbe AB, Adeyoju A, Yardumian A, Akinyanju O, Morris J, Westerdale N, et al. A prospective diary study of stuttering priapism in adolescents and young men with sickle cell anemia: report of an international randomized control trial--the priapism in sickle cell study. J Androl. 2011;32(4):375-82.

[110] Adeyoju AB, Olujohungbe AB, Morris J, Yardumian A, Bareford D, Akenova A, et al. Priapism in sickle-cell disease; incidence, risk factors and complications - an international multicentre study. BJU Int. 2002;90(9):898-902.

[111] Powars DR, Johnson CS. Priapism. Hematol Oncol Clin North Am. 1996;10(6):1363-72.

[112] Rogers ZR. Priapism in sickle cell disease. Hematol Oncol Clin North Am. 2005;19(5):917-28, viii.

[113] Sharpsteen JR, Jr., Powars D, Johnson C, Rogers ZR, Williams WD, Posch RJ. Multisystem damage associated with tricorporal priapism in sickle cell disease. Am $\mathrm{J}$ Med. 1993;94(3):289-95.

[114] Okpala I, Westerdale N, Jegede T, Cheung B. Etilefrine for the prevention of priapism in adult sickle cell disease. Br J Haematol. 2002;118(3):918-21.

[115] Emond AM, Holman R, Hayes RJ, Serjeant GR. Priapism and impotence in homozygous sickle cell disease. Arch Intern Med. 1980;140(11):1434-7.

[116] Mantadakis E, Cavender JD, Rogers ZR, Ewalt DH, Buchanan GR. Prevalence of priapism in children and adolescents with sickle cell anemia. J Pediatr Hematol Oncol. 1999;21(6):518-22.

[117] Allue Lopez M, Garcia de Jalon Martinez A, Pascual Regueiro D, Mallen Mateo E, Villanueva Benedicto A, Rioja Sanz LA. Priapism as an initial presentation of chronic myeloid leukaemia. Actas Urol Esp. 2004;28(5):387-9.

[118] Gregory AB, Ates K, Trinity JB, Hussein G, Ajay N, Rany S. Priapism: Pathogenesis, epidemiology, and management. J Sex Med. 2010;7:476-500.

[119] Kato GJ. Priapism in sickle-cell disease: a hematologist's perspective. J Sex Med. 2011;1:70-8.

[120] Morano SG, Latagliata R, Carmosino I, Girmenia C, Dal Forno S, Alimena G. Treatment of long-lasting priapism in chronic myeloid leukemia at onset. Ann Hematol. 2000;79(11):644-5.

[121] Rodgers R, Latif Z, Copland M. How I manage priapism in chronic myeloid leukaemia patients. Br J Haematol. 2012;158(2):155-64.

[122] Serjeant GR, de Ceulaer K, Maude GH. Stilboestrol and stuttering priapism in homozygous sickle-cell disease. Lancet. 1985;2(8467):1274-6. 
[123] Mantadakis E, Ewalt DH, Cavender JD, Rogers ZR, Buchanan GR. Outpatient penile aspiration and epinephrine irrigation for young patients with sickle cell anemia and prolonged priapism. Blood. 2000;95(1):78-82.

[124] Talacki CA, Ballas SK. Modified method of exchange transfusion in sickle cell disease. J Clin Apher. 1990;5(4):183-7.

[125] Baron M, Leiter E. The management of priapism in sickle cell anemia. J Urol. 1978;119(5):610-1.

[126] Seeler RA. Intensive transfusion therapy for priapism in boys with sickle cell anemia. J Urol. 1973;110(3):360-3.

[127] Rackoff WR, Ohene-Frempong K, Month S, Scott JP, Neahring B, Cohen AR. Neurologic events after partial exchange transfusion for priapism in sickle cell disease. J Pediatr. 1992;120(6):882-5.

[128] Siegel JF, Rich MA, Brock WA. Association of sickle cell disease, priapism, exchange transfusion and neurological events: ASPEN syndrome. J Urol. 1993;150(5 Pt 1):1480-2.

[129] Ballas SK, Lyon D. Safety and efficacy of blood exchange transfusion for priapism complicating sickle cell disease. J Clin Apher. 2016;31(1):5-10.

[130] Dawson C, Whitfield H. ABC of Urology. Urological emergencies in general practice. BMJ. 1996;312(7034):838-40.

[131] Gradisek RE. Priapism in sickle cell disease. Ann Emerg Med. 1983;12(8):510-2.

[132] Banerjee S, Owen C, Chopra S. Sickle cell hepatopathy. Hepatology. 2001;33(5):1021-8.

[133] Hatton CS, Bunch C, Weatherall DJ. Hepatic sequestration in sickle cell anaemia. Br Med J (Clin Res Ed). 1985;290(6470):744-5.

[134] Shao SH, Orringer EP. Sickle cell intrahepatic cholestasis: approach to a difficult problem. Am J Gastroenterol. 1995;90(11):2048-50.

[135] Almeida A, Roberts I. Bone involvement in sickle cell disease. Br J Haematol. 2005;129(4):482-90.

[136] Hassell KL, Eckman JR, Lane PA. Acute multiorgan failure syndrome: a potentially catastrophic complication of severe sickle cell pain episodes. Am J Med. 1994;96(2):155-62.

[137] Stevens MC, Padwick M, Serjeant GR. Observations on the natural history of dactylitis in homozygous sickle cell disease. Clin Pediatr (Phila). 1981;20(5):311-7.

[138] Shaiova L, Wallenstein D. Outpatient management of sickle cell pain with chronic opioid pharmacotherapy. J Natl Med Assoc. 2004;96(7):984-6.

[139] Ballas SK, Barton FB, Waclawiw MA, Swerdlow P, Eckman JR, Pegelow CH, et al. Hydroxyurea and sickle cell anemia: effect on quality of life. Health Qual Life Outcomes. 2006;4:59.

[140] Kinney TR, Helms RW, O'Branski EE, Ohene-Frempong K, Wang W, Daeschner C, et al. Safety of hydroxyurea in children with sickle cell anemia: results of the HUG-KIDS study, a phase I/II trial. Pediatric Hydroxyurea Group. Blood. 1999;94(5):1550-4.

[141] Wang WC, Wynn LW, Rogers ZR, Scott JP, Lane PA, Ware RE. A two-year pilot trial of hydroxyurea in very young children with sickle-cell anemia. J Pediatr. 2001;139(6):7906.

[142] Hankins JS, Ware RE, Rogers ZR, Wynn LW, Lane PA, Scott JP, et al. Long-term hydroxyurea therapy for infants with sickle cell anemia: the HUSOFT extension study. Blood. 2005;106(7):2269-75. 
[143] Wang WC, Ware RE, Miller ST, Iyer RV, Casella JF, Minniti CP, et al. Hydroxycarbamide in very young children with sickle-cell anaemia: a multicentre, randomised, controlled trial (BABY HUG). Lancet. 2011;377(9778):1663-72.

[144] Alvarez O, Miller ST, Wang WC, Luo Z, McCarville MB, Schwartz GJ, et al. Effect of hydroxyurea treatment on renal function parameters: results from the multi-center placebo-controlled BABY HUG clinical trial for infants with sickle cell anemia. Pediatr Blood Cancer. 2012;59(4):668-74.

[145] Aygun B, Mortier NA, Smeltzer MP, Shulkin BL, Hankins JS, Ware RE. Hydroxyurea treatment decreases glomerular hyperfiltration in children with sickle cell anemia. Am J Hematol. 2013;88(2):116-9.

[146] Lebensburger JD, Miller ST, Howard TH, Casella JF, Brown RC, Lu M, et al. Influence of severity of anemia on clinical findings in infants with sickle cell anemia: analyses from the BABY HUG study. Pediatr Blood Cancer. 2012;59(4):675-8.

[147] Ware RE, Davis BR, Schultz WH, Brown RC, Aygun B, Sarnaik S, et al. Hydroxycarbamide versus chronic transfusion for maintenance of transcranial doppler flow velocities in children with sickle cell anaemia-TCD With Transfusions Changing to Hydroxyurea (TWiTCH): a multicentre, open-label, phase 3, non-inferiority trial. Lancet. 2016;387(10019):661-70.

[148] Oncologic Drugs Advisory Committee. Oral L-Glutamine Powder for the Treatment of Sickle Cell Disease NDA 208587 Oncologic Drugs Advisory Committee; 2017.

[149] Kaul DK, Tsai HM, Liu XD, Nakada MT, Nagel RL, Coller BS. Monoclonal antibodies to alphaVbeta3 (7E3 and LM609) inhibit sickle red blood cell-endothelium interactions induced by platelet-activating factor. Blood. 2000;95(2):368-74.

[150] Adams-Graves P, Kedar A, Koshy M, Steinberg M, Veith R, Ward D, et al. RheothRx (poloxamer 188) injection for the acute painful episode of sickle cell disease: a pilot study. Blood. 1997;90(5):2041-6.

[151] Ohnishi ST, Ohnishi T, Ogunmola GB. Green tea extract and aged garlic extract inhibit anion transport and sickle cell dehydration in vitro. Blood Cells Mol Dis. 2001;27(1):148-57.

[152] Ballas SK. Hydration of sickle erythrocytes using a herbal extract (Pfaffia paniculata) in vitro. Br J Haematol. 2000;111(1):359-62.

[153] Singh PC, Ballas SK. Emerging drugs for sickle cell anemia. Expert Opin Emerg Drugs. 2015;20(1):47-61.

[154] Machado RF, Barst RJ, Yovetich NA, Hassell KL, Kato GJ, Gordeuk VR, et al. Hospitalization for pain in patients with sickle cell disease treated with sildenafil for elevated TRV and low exercise capacity. Blood. 2011;118(4):855-64.

[155] Ballas SK, Bauserman RL, McCarthy WF, Castro OL, Smith WR, Waclawiw MA. Hydroxyurea and acute painful crises in sickle cell anemia: effects on hospital length of stay and opioid utilization during hospitalization, outpatient acute care contacts, and at home. J Pain Symptom Manage. 2010;40(6):870-82.

[156] Head CA, Swerdlow P, McDade WA, Joshi RM, Ikuta T, Cooper ML, et al. Beneficial effects of nitric oxide breathing in adult patients with sickle cell crisis. Am J Hematol. 2010;85(10):800-2.

[157] Gladwin MT, Kato GJ, Weiner D, Onyekwere OC, Dampier C, Hsu L, et al. Nitric oxide for inhalation in the acute treatment of sickle cell pain crisis: a randomized controlled trial. JAMA. 2011;305(9):893-902. 
[158] Walters MC, Storb R, Patience M, Leisenring W, Taylor T, Sanders JE, et al. Impact of bone marrow transplantation for symptomatic sickle cell disease: an interim report. Multicenter investigation of bone marrow transplantation for sickle cell disease. Blood. 2000;95(6):1918-24.

[159] Johnson FL, Mentzer WC, Kalinyak KA, Sullivan KM, Abboud MR. Bone marrow transplantation for sickle cell disease. The United States experience. Am J Pediatr Hematol Oncol. 1994;16(1):22-6.

[160] Vermylen C, Cornu G. Bone marrow transplantation for sickle cell disease. The European experience. Am J Pediatr Hematol Oncol. 1994;16(1):18-21.

[161] Vermylen C, Cornu G, Ferster A, Brichard B, Ninane J, Ferrant A, et al. Haematopoietic stem cell transplantation for sickle cell anaemia: the first 50 patients transplanted in Belgium. Bone Marrow Transplant. 1998;22(1):1-6.

[162] Walters MC. Bone marrow transplantation for sickle cell disease: where do we go from here? J Pediatr Hematol Oncol. 1999;21(6):467-74.

[163] Buchanan G, Vichinsky E, Krishnamurti L, Shenoy S. Severe sickle cell disease-pathophysiology and therapy. Biol Blood Marrow Transplant. 2010;16(1 Suppl):S64-7.

[164] Krishnamurti L, Kharbanda S, Biernacki MA, Zhang W, Baker KS, Wagner JE, et al. Stable long-term donor engraftment following reduced-intensity hematopoietic cell transplantation for sickle cell disease. Biol Blood Marrow Transplant. 2008;14(11):12708.

[165] Shenoy S, Grossman WJ, DiPersio J, Yu LC, Wilson D, Barnes YJ, et al. A novel reduced-intensity stem cell transplant regimen for nonmalignant disorders. Bone Marrow Transplant. 2005;35(4):345-52.

[166] Walters MC, Patience M, Leisenring W, Eckman JR, Buchanan GR, Rogers ZR, et al. Barriers to bone marrow transplantation for sickle cell anemia. Biol Blood Marrow Transplant. 1996;2(2):100-4.

[167] Walters MC, Quirolo L, Trachtenberg ET, Edwards S, Hale L, Lee J, et al. Sibling donor cord blood transplantation for thalassemia major: Experience of the Sibling Donor Cord Blood Program. Ann N Y Acad Sci. 2005;1054:206-13.

[168] Al Jefri AH. Advances in allogeneic stem cell transplantation for hemoglobinopathies. Hemoglobin. 2011;35(5-6):469-75.

[169] Friedrich MJ. Advances reshaping sickle cell therapy. JAMA. 2011;305(3):239-40.

[170] Locatelli F, Pagliara D. Allogeneic hematopoietic stem cell transplantation in children with sickle cell disease. Pediatr Blood Cancer. 2012;59(2):372-6.

[171] Forget B, G. Gene therapy. In: Embury SH, Hebble, R. P., Mohandas, N., Steinberg, M. H., editor. Sickle Cell Disease: Basic Principles and Clinical Practice. New York: Raven Press; 1994. p. 853-60.

[172] Cole-Strauss A, Yoon K, Xiang Y, Byrne BC, Rice MC, Gryn J, et al. Correction of the mutation responsible for sickle cell anemia by an RNA-DNA oligonucleotide. Science. 1996;273(5280):1386-9.

[173] Cavazzana-Calvo M, Payen E, Negre O, Wang G, Hehir K, Fusil F, et al. Transfusion independence and HMGA2 activation after gene therapy of human beta-thalassaemia. Nature. 2010;467(7313):318-22.

[174] Dong A, Rivella S, Breda L. Gene therapy for hemoglobinopathies: progress and challenges. Transl Res. 2013;161(4):293-306. 
[175] Payen E, Leboulch P. Advances in stem cell transplantation and gene therapy in the betahemoglobinopathies. Hematology Am Soc Hematol Educ Program. 2012;2012:276-83.

[176] Persons DA. Hematopoietic stem cell gene transfer for the treatment of hemoglobin disorders. Hematology Am Soc Hematol Educ Program. 2009:690-7. 